\title{
A Központi Statisztikai Hivatal 1956-ban
}

Kovács Csaba,

a KSH Könyvtár történészkézirattárosa

E-mail: Csaba.Kovacs@ksh.hu
A tanulmány azt mutatja be, mi történt a KSH (Központi Statisztikai Hivatal) falai között az 1956-os forradalom és szabadságharc idején, valamint az azt követő hónapokban. A szerző a vonatkozó szakirodalom mellett többféle forrást hasznosít, egyrészt belügyi iratanyagot, pontosabban az 1956-os események kapcsán összeállított nyomozati, megfigyelési anyagot. Másrészt megjelenik a cikkben az elbeszélő források közé tartozó életútinterjú és önéletírás is. Az olvasó az országos események sodrába illesztve nyomon követheti a forradalmi szervek, a forradalmi bizottság és a nemzetőrség tevékenységét, valamint kirajzolódik a $\mathrm{KSH}$ eseményekben játszott szerepe is.

\section{TÁRGYSZÓ:}

Statisztikatörténet.

1956-os események.

Hivataltörténet.

DOI: 10.20311/stat2017.11-12.hu1100 
A forradalom és szabadságharc meglepő módon nem a sztálini típusú rákosista diktatúra éveiben (1949-1953) robbant ki, hanem a későbbi mártír miniszterelnök, Nagy Imre igen komoly politikai-gazdasági-társadalmi enyhülést hozó első, 1953 és 1955 közötti miniszterelnökségét követően, amikor a rendszer kezdett ismét merevebbé válni (Romsics [2010] 376-384. old.). A visszarendeződés ellenében megfogant vitaestek, rendezvények, összejövetelek csúcspontja az 1956. október 23-ai tömegdemonstráció volt, amely estére a rendszer elleni fegyveres fellépéssé vált.

\section{A KSH-ban történteket összefoglaló kormányzati anyagok tartalma}

Az országban zajló események szinte rögtön begyürüztek a KSH falai közé is. Az azokat bemutató források egyike a hivatal ún. objektumdossziéja, amelyet egy 1965. január 21-ei határozatot követően nyitott meg a BM (Belügyminisztérium), ugyanis meglátása szerint a KSH „olyan országos hatáskörü szerv, amely munkájánál fogva átfogja a Magyar Népköztársaság állami társadalmi és gazdasági tevékenységét", államtitkokat őriz, így a külföldi hírszerzői tevékenységnek is ki van téve, ezért operatív ellenőrzése, ahhoz kapcsolódóan pedig objektumdosszié megnyitása szükséges. ${ }^{1}$ A megnyitására tett javaslat indoklásában az államvédelmi tiszt megemlítette, hogy a káderhelyzetet vizsgálva kiderült, több gyanús, részleges ellenőrzés alatt álló vagy ellenörzésre szoruló személy dolgozik az intézménynél. A BM operatív bünügyi nyilvántartásában ekkor 98 fő szerepelt, 63 személy pedig rendszeresen levelezett nyugati kapcsolattal, ennél fogva úgy találták „Nyugtalanító a helyzet az államtitkok kezelése, őrzése területén is. Az elmúlt hónapokban végrehajtott ellenőrzések bizonyították, hogy a jelenlegi állapotok nem biztosítják, hogy illetéktelenek jogosulatlanul, vagy ellenséges célzattal ne tudják megszerezni az államtitkokat képező adatokat."

A jelentés írója kitért a hivatalban 1956-ban történtekre is. Az eseményeket összegezve papírra vetette, hogy a KSH-ban Forradalmi Bizottság és Nemzetőrség is alakult (elöbbi 54, utóbbi 28 tagot számlált), s hogy azok kapcsolatot tartottak a

${ }^{1}$ ÁBTL: O-19827. I. köt. Idézet: 11. old.

2 ÁBTL: O-19827. I. köt. 12. old.

Statisztikai Szemle, 95. évfolyam 11-12. szóm 
Széna téri, illetve a Fő utcában tevékenykedő felkelőkkel. Ezért az „ellenforradalom leverése után a »Nemzetôrség « 4 tagját a bíróság különböző börtönbüntetésekre ítélte, míg két fővel szemben preventív, megelőző őrizetbe vételt alkalmaztak." 3

Az objektumdosszié kiemelte azt is, hogy a Forradalmi Bizottság szerepe 1956 novembere, vagyis tulajdonképpen megszűnése után is jelentős volt, hiszen ,az 1957 februárban végrehajtott racionalizálást, vagyis elbocsájtási hullámot a Hivatal akkori vezetői a »Forradalmi Bizottság«-gal tárgyalták meg és így nem az ellenforradalomban kompromittált személyeket, hanem más dolgozókat bocsájtottak el." ${ }^{14}$ Mindezt alátámasztja a KSH-ban 1957 januárjában múködő ideiglenes szakszervezeti bizottság nyilatkozata, mely szerint az 1956. október 23-ával kezdődött eseménysorozatot, mint „szent célokat” kitűző forradalmat értékelte. S ahhoz, hogy a független és demokratikus ország minden állampolgára egységes emberi jogokkal rendelkezhessen, szabad szakszervezetek munkájára van szükség, amelyekre nincs hatással az állam és a párt. Az ideiglenes szakszervezeti bizottság - amely 1956. december 6-án, vagyis a Forradalmi Bizottság megszűnését követő napon alakult - mindezen alapfelvetések okán nem tekintette a Magyar Közalkalmazottak Szakszervezetét oly grémiumnak annak vezetőségét nem is ismerte el és deklarálta, hogy utasítást sem fogad el tőle -, amely képviselni tudja a dolgozók érdekeit. Álláspontja szerint ugyanis a Magyar Közalkalmazottak Szakszervezete nem független, nem elsődleges céljuk a dolgozói érdekképviselet, illetve felépítése sem demokratikus. ${ }^{5}$ Az említett elbocsájtások mellett a KSH személyi állományát érintö újabb veszteségként könyvelhetö el, hogy az 1956-os eseményeket követően 30 fö elhagyta az országot. ${ }^{6}$

Az összesítés szerint a forradalom és szabadságharc alatti események miatt nyolc KSH-s személy - Zsámboki Zoltán, Szalai Sándor, Szönyi Gyula, Balogh Gyula, Laki István, Moró Károly, Niklai Ádám és Nobilis Gábor - ellen indult bírósági eljárás. ${ }^{7}$ Közülük négyet el is ítéltek, Zsámboki Zoltánra 6 évnyi (a többi forrásban és az életútinterjúban is 7 év szabadságvesztés szerepel), ${ }^{8}$ Szalai Sándorra 1 év 2 havi, Moró Károlyra 1 évnyi (3 évre felfüggesztve), Szőnyi Gyulára pedig 1 évnyi (3 évre felfüggesztve) börtönbüntetést róttak ki. Laki Istvánt és Balogh Gyulát szabadlábra helyezték. Preventív, megelőző őrizetbe vételt alkalmaztak Niklai Ádámmal és Nobilis Gáborral szemben, utóbbit később illegális szervezkedés vádjával újra őrizetbe vették. ${ }^{9}$

${ }^{3}$ ÁBTL: O-19827. I. köt. Idézet: 23. old.

${ }^{4}$ ÁBTL: O-19827. I. köt. 23. old.

${ }^{5}$ ÁBTL: O-10087. Nyilatkozat. A Központi Statisztikai Hivatal Ideiglenes szakszervezeti bizottsága. 1957. január 10. 38. old.

${ }^{6}$ ÁBTL: O-19827. I. köt. 23. old.

${ }^{7}$ ÁBTL: V-150361/1. Központi Statisztikai Hivatal. 1959. augusztus 15. 276-277. old.

${ }^{8}$ ÁBTL: V-166931/8. Zsámboki Zoltán. 1990. 615-617. old.

${ }^{9}$ ÁBTL: V-150361/1. 278. old. 


\section{A belügyi informátor jelentése}

Az 1956-tal kapcsolatos eseményekről közvetít a „Naményi” nevü informátor 1966. január 6-i jelentése is. ${ }^{10}$ Naményi szerint már az „ellenforradalom” kitörése elött érezhető volt az alkalmazottak körében ,a hibákat túlhajtó Irodalmi Újság és a Petőfi Kör szelleme". ${ }^{11}$ (Az Irodalmi Újság a Magyar Írók Szövetségének lapja volt, amely a rákosista diktatúra ellenében az irodalom területén, de a közélet egyéb területein is kibontakozó véleménynyilvánítás egyik fórumává vált. A folyóirat forradalmi száma jó néhány, azóta emblematikussá vált írással 1956. november 2-án jelent meg; az újságot ezt követően be is tiltották. A Petőfi Kör a DISZ (Dolgozó Ifjúság Szövetség) berkein belül alakult 1955. március 25-én. A Kossuth Klubban müködő szervezet baloldali fiatal értelmiségiek társasági, közösségi, közéleti csoportosulása volt. Vitáik légköre és mondandója Nagy Imre 1953-1955 közötti kormányzati, gazdasági elképzeléseivel volt rokonítható, egyfajta előszelét jelentették az 1956. október 23-án kirobbant forradalomnak.) A jelentés alapján Naményi a KSH Közgazdasági föosztályán dolgozott 1956-ban, így beszámolója e szervezeti egységnél zajlott eseményekről szolgál számos részlettel. Előzmény gyanánt - elmondása szerint - a föosztály két dolgozója, Zsámboki Zoltán és Ferge Sándorné számoltak be az érdeklődőknek az Írószövetség és a Petőfi Kör rendezvényeiről vagy a Nagy Imre lakásán tartott találkozókról. „Fergéné szervezte a hivatal dolgozói körében a Petőfi kör tagságát, ő osztotta ki a belépési nyilatkozatokat is. A Petőfi kör polgárjogot nyert a hivatalokban, miután Péter elvtárs is tartott azon előadást, s a dolgozók egy része munkaidő alatt eljárt ezekre az összejövetelekre." ${ }^{2}$ A hivatal élén ekkor Péter György állt. (Kovács-Marton-Nádudvari [2014]) Két évtizeden át volt a KSH elnöke, és megítélése meglehetősen vegyes, ugyanis ő volt az, aki 1948-ban levezényelte a polgári elemek eltávolítását, megroppantva ezáltal jó néhány életpályát, karriert, illetve egzisztenciát. Ugyanakkor ő volt az a személy is, aki a későbbiekben a kormányzat és a belügy ellenében sokszor kiállt a hivatal és kollégái védelmében. A kormányzattal ambivalenssé váló kapcsolatának lezárásaként, külföldi protokolláris és munkaútjaival összefüggően, devizával való visszaéléssel vádolták meg - a személye elleni támadás elválaszthatatlan igen aktív gazdaságpolitikai szerepétől, amelynek keretében számos területen fogalmazta meg reformközgazdasági elképzeléseit -, amiatt állásából fel is függesztették. Bár a vádakat nem bizonyították, Péter György a rá nehezedő nyomás elöl 1969 januárjában az öngyilkosságba menekült (Pajcsics [2006]).

A további eseményekről az informátor napokra lebontva számolt be. Megemlítette, hogy Zsámboki már egy nappal korábban jelezte az október 23-ára tervezett tüntetést, $\mathrm{s}$

\footnotetext{
${ }^{10}$ ÁBTL: O-19827. I. köt. 44-48. old.

11 ÁBTL: O-19827. I. köt. 44. old.

${ }^{12}$ ÁBTL: O-19827. I. köt. 45. old.
} 
hogy kollegáit az azon való részvételre buzdította. Másnap az alkalmazottak közül nem mindenki ment be a munkahelyére, a bent levőket viszont Zala Júlia (FenyvesiKovács-Nádudvari [2014]) arra kérte, hogy végezzék munkájukat, a kormányt pedig igyekezzenek tájékoztatni. Munkavégzés helyett azonban az események megvitatása folyt, sőt az országszerte megalakuló nemzetörségek és a forradalmi bizottságok mintájára Zsámboki Zoltán, Móró Károly és Szőnyi Gyula szorgalmazta e szervek KSH-n belüli létrehozását is. „A nemzetőrséget azzal indokolták, hogy a hivatal vagyonát kell megvédeni, így abban elég szélesen be is kapcsolódtak a dolgozók."13 Október 25-én megalakították a Forradalmi Bizottságot, amit azonban sokan nem ismertek el, így a hónap végén, október 31-én újat alakítottak. Naményi elmondása szerint a választást követően a hivatal vezetését egy három főből álló bizottság látta el, annak Fazekas Béla, a KSH egyik akkori elnökhelyettese, Szalai Sándor és egy harmadik, Naményi által meg nem nevezett személy voltak a tagjai. A bizottság elnöki tisztét Niklai Ádám töltötte be, tagjai között volt Zsámboki, Tarr József és több másik alkalmazott. A Forradalmi Bizottság ülései a kis tanácsteremben zajlottak. Felállt a Nemzetőrség is, ennek parancsnoka Virág János lett. „A nemzetőri szoba a földszinten a jelenlegi /Fazekas elvtárs szobája/ mezőgazdasági főosztályon volt. Itt tartózkodtak az ellenforradalom hangadói is a nemzetőrsön, bár 2-3 napig jóformán csak tervezgettek, mert fegyver nem volt, örség nem állt sehol, a nemzetörség csak névleg volt őrség." ${ }^{14}$ Naményi szerint a megmozdulásokkal szimpatizálók tervbe vették a rákosista elemek és a Személyzeti osztály alkalmazottainak eltávolítását is, továbbá az ÁVH (Államvédelmi Hatóság) informátorainak kiléte felől is érdeklődtek Varga Gyulánál, aki ekkor a Személyzeti osztályt vezette. Időközben felvették a kapcsolatot a kerületi nemzetőrséggel és fegyvereket kértek tőlük. Október 29-e körül puskákhoz és egy golyószóróhoz is hozzájutottak - utóbbi meghatározásában Naményi nem volt teljesen biztos. A fegyvereket szétosztották, azokat azonban nem használták, jó részüket meg sem tisztították. A nemzetőri szobának nagy volt a forgalma, gyakran keresték fel a kerületből vagy más szervtől, egy ízben például két idősebb férfi azzal a céllal, hogy a Kisgazda Pártot szervezzék a hivatalban. Az informátor adalékként megemlítette azt is, hogy a nemzetőri szobában tiltott volt az elvtárs megszólítás. Naményi ezt követően november 5-éig nem ment be a KSH-ba, november 4-én csak kevesen jelentek meg a hivatalban. A nemzetőri szobában elégették az iratokat, majd miután kiürült az épület, csak egy hivatalsegéd maradt bent, aki lövöldözni kezdett az ablakból. November 5-e után az addig is hangadók sztrájkot, valamint az abba történő bekapcsolódást szervezték. A Forradalmi Bizottság is rendszeresen ülésezett, céljuk az volt, hogy eltávolítsák a hivatalból a forradalmi eszmékkel nem szimpatizálókat, azonban - Naményi szerint - döntéseiknek már nem tudtak érvényt szerezni. ${ }^{15}$ Ennek ellentmond a KSH-ról szóló objektum-

\footnotetext{
${ }^{13}$ ÁBTL: O-19827. I. köt. 45. old.

${ }^{14}$ ÁBTL: O-19827. I. köt. 45. old.

${ }^{15}$ ÁBTL: O-19827. I. köt. 45-48. old.
} 
dosszié, amely szerint az egykori Forradalmi Bizottság tagjai érvényesíteni tudták szempontjaikat az elbocsájtandók személyét illetően. Az informátor beszámolójához kiegészítésképp hozzátehető, hogy a kihallgatott Móró Károly szerint nemcsak a Kisgazda Párt, hanem a Szociáldemokrata Párt és a Nemzeti Parasztpárt képviselői is megjelentek az intézményben. Egyrészt engedélyt kértek a hivatalon belüli pártszervezésre, másrészt miután a hivatal saját autóparkkal rendelkezett, egy-két alkalommal autót is kértek kölcsön. Mindezek mellett a KSH-n belül is történt kísérlet különböző pártok megszervezésére, ezeket azonban nem tudták ellenőrizni. Móró megjegyezte, hogy a Közgazdasági föosztályon dolgozó Zala Júliáról elterjedt hír - miszerint a Szociáldemokrata Pártot igyekezett szervezni - rágalom. ${ }^{16}$

Az említett Fazekas Bélát is kihallgatták, tanúvallomása alapján az ideiglenes Forradalmi Bizottság október 27-én állt fel, azt 30-35 dolgozó választotta meg, feladatául a személyi állomány és a statisztikai szakanyag védelmét és a végleges Forradalmi Bizottság megválasztásának előkészitését szánták. Utóbbi munkát végül egy másik dolgozói csoport látta el. A választást előkészítők összeállítottak egy nagyjából 100 nevet tartalmazó listát, rájuk lehetett voksolni, majd a listát mindenki megkapta másolatban. Fazekas szerint a szavazáskor Niklai Ádám rákérdezett a szavazás módjára, így az végül föosztályonként zajlott. Majd Szalai Sándor azon lista elfogadása mellett szólalt fel, amely a kitiltandók nevét tartalmazta. Fazekas elmondása szerint a saját föosztályán tartott választáson sem vett részt, ugyanis időközben fegyveresek jelentek meg az épületben, akik Klimes Lajos és Varga Gyula fogva tartásának és kihallgatásának hírét közölték, öt pedig nem engedték ki a szobájából. Közben a páncélszekrények kulcsát keresték, majd miután azokat nem találták, elvitték iratainak egy részét. Beszámolt arról is, hogy a választási gyülésen elfogadták a vezetők és a pártemberek kitiltásra vonatkozó javaslatot, s helytelenítették Klimes és Varga fogva tartását. A Forradalmi Bizottságba végül 78 föt választottak be. ${ }^{17}$

\section{A belügyi dossziék tartalmából}

Az 1956. őszi eseményeket összefoglaló anyagok mellett a történések nyomon követhetök a letartóztatottak, elítéltek, megfigyeltek belügyi anyagai révén is. Jelen munkához három, a KSH-s történések fősodrában levő személy anyagait néztem át, Móró Károlyét, Szőnyi Gyuláét, illetve Zsámboki Zoltánét. A belügyi iratokból nyert információk általában megerösítik, vagy akár ki is egészítik az ismertetett összefoglaló-jelentést és az informátortól hallottakat, olykor azonban - ahogy néha már eddig

\footnotetext{
${ }^{16}$ ÁBTL: O-10087. Feljegyzés. 1957. március 22. 40. old.

${ }^{17}$ ÁBTL: O-10087. Feljegyzés. 1957. március 8. 43-44. old.
} 
is látszódott - a két vagy több forrásból származó leírásokat összevetve ellentmondások, pontatlanságok adódnak.

\subsection{Móró Károly ügye}

Móró Károlyt ellenforradalmi tevékenység miatt 1957. március 13-án vették megelőző őrizetbe, azonban kihallgatása közben nem tett mindenre kiterjedő, ún. felderítő vallomást, és társairól is csak általánosságokat mondott. ${ }^{18}$ Mindezek ellenére a belügy az operatív anyagok összegyüjtése, elemzése után - azokra megfigyeléssel, tanúkihallgatással, nyomozati tevékenységgel tettek szert - bünösnek ítélte Mórót aktív ellenforradalmi cselekmények végrehajtása miatt. Fontos persze hozzátenni, hogy épp azért, mert a belügy állította össze az anyagot, nem tekinthető minden részlete megbízhatónak. Hiszen egyrészt, bár meglepően cizellált kép rajzolódik ki belőlük, elég csak annyit tudni, hogy mind a vádlottat vagy megfigyelt személyt, mind pedig az ügy során meghallgatott tanúkat bántalmazhatták, megfélemlíthették, zsarolhatták vagy egyéb módón befolyásolhatták, amelyek miatt a vallomások, kihallgatások, beszámolók nemcsak torzíthatnak, hanem akár valótlan tartalmat is hordozhatnak. Másrészt pedig a diktatúrát kiszolgáló, annak hatalmát erősítő belügy sajátos szempontok szerint ítélt fontosnak egyes eseményeket, jelenségeket, másokat pedig teljességgel ignorálhatott, így összességében egyoldalú, tulajdonképpen torz kép rajzolódhat ki a történésekról. Mindenestre a Móró ellen megfogalmazott vádak közé tartozott például, hogy nemzetőr volt, s ebbéli tisztében aktív fegyveres szolgálatot teljesített. Tagja volt továbbá annak a nemzetôri különítménynek is, amely a KSH-ban több vezető kommunistát tartóztatott le, motozott meg, majd hallgatott ki. ${ }^{19}$ Mindezek mellett „felszólalásai, személyes agitációi eredményeként kialakult a KSH-ban az a légkör, amelynek következtében a »forradalmi bizottság « keresztül tudta vinni, hogy a Hivatalból több mint 40 kommunistát a »forradalmi bizottság« kitiltott". ${ }^{20}$

Móró anyagában is olvasható, hogy miután 1956. december 5-én az új rezsim az országban még müködő forradalmi bizottságokat megszünésre ítélte (Romsics [2010] 405. old.), a KSH Forradalmi Bizottsága munkájának beszüntetése előtt még közzétett egy müködéséről szóló és szellemiségét tükröző nyilatkozatot, mely szerint október 23-a után a bizottságot a szükség hívta életre, működése alatt mindvégig megvolt irányába a dolgozók támogatása. „A dolgozók bizalma adott lehetőséget ahhoz is,

18 ÁBTL: B-83736. Tanulmányozási terv. 1957. október 25. „Paprikás” fn. ügynökjelölt. 7. old.

${ }^{19}$ ÁBTL: O-10087. Határozat. 1958. május 28. Móró Károly ügyében személyi dosszié nyitásáról szóló. 25. old.

${ }^{20}$ ÁBTL: O-10087. Összefoglaló jelentés. 1958. május 7. Móró Károly ügyében folytatott ügynöki bizalmas nyomozásról. 56-57. old.

Statisztikai Szemle, 95. évfolyam 11-12. szám 
hogy $[\ldots]$ olyan fontos és közérdekü ügyekben határozzon, mint a harci cselekmények következtében kárt szenvedettek megsegítése, a szükséglakások biztosítása, élelembeszerzés megindítása, a Hivatalt ért károk kijavítása, a munka felvétele, stb." Ezen érdemeket a nyilatkozat szerint a hivatal vezetősége is elismerte. Mindezek mellett a Forradalmi Bizottság azt is leszögezte, hogy mindvégig kitartottak az össznépi forradalmi események mellett, amelyet a Kádár-rezsim ellenforradalomnak bélyegzett, és kijelentették, hogy Magyarországnak ,független, demokratikus országnak kell lennie", s e követelések mellett továbbra is kiállnak. Majd a következő felhívást intézték az intézmény dolgozóihoz: „A Forradalmi Bizottság felhívja a Hivatal minden becsületes dolgozóját, hogy továbbra is tartson ki a forradalom szent és igaz ügye mellett és ne térjenek le az útról, amelyet a boldogabb jövőért életüket áldozott ifjak és munkások vére jelölt ki." ${ }^{21}$ A Nemzetőrség és a Forradalmi Bizottság munkájában résztvevők tevékenységének a szakszervezetbe történő áthelyezésében Mórónak is aktív szerepe volt, így az újabb ponttal gyarapította a kormányzat által felállított bűnlajstromot. Móró Károlyt egyébként 1957 derekán a KSH állásából elbocsájtotta, mert még ekkor is ágált a párt, a kormány és a szovjetek ellen. ${ }^{22}$

$\mathrm{Az}$ anyagban a személyesen tett vallomások mellett a tanúkihallgatási jegyzökönyvek azok, amelyek kiváltképp informatívak az 1956. őszi eseményekre vonatkozóan, úgymond a megfogalmazott vádakat részletekkel töltik meg. Olykor a tanú beszámolója meglehetősen szükszavú volt, Tilcsik Jenőné részéről például annyi hangzott el mindösszesen, hogy Móró nemzetőrként volt jelen az 1956. november 1jén tartott, Forradalmi Bizottságot megválasztó gyülésen, ,mintegy biztosítva a színpadon helyet foglaló »forradalmi bizottság « elnökségét”. ${ }^{23}$ Akadt viszont jó néhány olyan tanúvallomás, amely sokkalta bőbeszédübb volt. Olajos Árpád - aki egyébként 1956 öszén nemzetőr volt - minősítette is egykori kollégáját. Elmondása szerint „mint párttagot ismertem meg, de nem kellett hosszú idő ahhoz, hogy megállapítsam, hogy nem híve a népidemokráciának”. A jegyzőkönyvben foglaltak szerint Móró „az ellenforradalom alatt már az első perctől az egyik leghangosabb ember volt”, Szegeden élő családjától pedig már a forradalom kitörése előtt kapott információkat a készülődő eseményekről. ${ }^{24}$ Egy, a rezsim szemében újabb terhelő történet megmutatta egyébként, hogy 1956-ra a fiatal értelmiségiek a korábbi évek tapasztalatai után milyen mértékben elutasították a sztálini diktatúrát, a totális állami önkényt és annak minden velejáróját (Standeisky [2007] 173-174. old.), sőt még azokat is, akik szervilis módon viszonyultak ahhoz. Szintúgy Olajos elmondása alapján a következő törold.

${ }^{21}$ ÁBTL: O-10087. Nyilatkozat. Központi Statisztikai Hivatal Forradalmi Bizottság. 1956. december 5. 35.

${ }^{22}$ ÁBTL: O-10087. Összefoglaló jelentés. 1958. május 7. Móró Károly ügyében folytatott ügynöki bizalmas nyomozásról. 57. old.

${ }^{23}$ ÁBTL: O-10087. Tilcsik Jenőné tanúkihallgatási jegyzőkönyve. 1958. április 25. 29. old.

${ }^{24}$ ÁBTL: O-10087. Olajos Árpád tanúkihallgatási jegyzőkönyve. 1958. március 12. 30. old. 
tént: Móró 1956. október 25-én komolyan összetüzött Réti Pálnéval, az egyik osztályvezetővel. Rétiné ugyanis Gerö Ernőt táviratban akarta biztosítani arról, hogy a KSH dolgozói támogatják, de mindez elmaradt, mert Móró sztálinistának és szélsőségesnek titulálta őt. Móró a nemzetőrség soraiba is belépett, a testület egyik szervezője volt, s ebbéli szerepében ÁVH-s megbízottak után nyomozott. A hivatalból eltávolítandók nevét tartalmazó lista összeállításában is - Zsámbokival és Szalaival együttmüködve - részt vett. ${ }^{25}$ Egy újabb tanúvallomás pedig a KSH Forradalmi Bizottságának 1956. november 1-jére datált megválasztásán történtek részleteire világított rá: eszerint Niklai Ádám, az Építőipari osztály helyettes vezetője „kifejtette, hogy az eddigi kommunista vezetők a magyar statisztikát rossz útra vitték [...] A régi jó statisztikusokat kirúgták a hivatalból és ezzel megsemmisítették a magyar statisztikának az egységes fejlődését." Majd mindehhez azt tette még hozzá, hogy le kell váltaniuk az elnököt és annak helyetteseit. Utóbbival - a tanú szerint - Szalai Sándor is egyet értett, $\mathrm{s}$ a vezetői feladatok ellátása végett egy háromtagú bizottság felállítását javasolta, amelynek munkájában Thirring Lajosnak és két 1945 és 1948 között elküldött statisztikusnak kellene részt vennie, s felvetette az intézményböl eltávolítandó személyeket tartalmazó névsor összeállitását is. A tanú Móró ÁVH-s kapcsolatok felkutatására vonatkozó kérdezősködését emelte ki. ${ }^{26}$

A KSH-ban levő állambiztonsági ügynökök felderítése állt Varga Gyula és Klimes Lajos kihallgatásának hátterében is. Varga elmondása szerint 1956. október 31-én éjjel ismeretlen fegyveresek jelentek meg a lakásán, majd a KSH épületébe vitték; Klimest útközben ,gyüjtötték be”. A tőle kért személyzeti nyilvántartást azonban nem tudta rendelkezésre bocsátani, mert az iroda kulcsát, ahol az iratokat őrizték, már korábban átadta a KSH Forradalmi Bizottságának. Varga elmondása alapján, ezt követően átvitték őket a Fő utcába, ahol újabb kihallgatáson azt tudakolták tőlük, hogy „Kik az áv. spiclik a KSH-ban és hol van a névsoruk”. Vargát november 2-án engedték szabadon, aki a Forradalmi Bizottság megszervezőiként Szalai Sándort, Zsámboki Zoltánt - ôt mérsékelt hangadóként jellemezte - és az időközben külföldre távozott Prigli Bélát jelölte meg. ${ }^{27}$ Klimes mondandója alapján a „,ö hangadók" közé tartozott Szőnyi Gyula, aki a fegyveres őrség vezetője és a Forradalmi Bizottság tagja volt, s mellette Tausz Gyulát, a gépkocsi mühely vezetöjét is aktív forradalmi szereplöként nevezte meg. ${ }^{28}$ Varga és Klimes mellett letartóztatták $M a$ gyar Miklóst is, őt - elmondása szerint - Móró, az időközben disszidált Virág János, a Közgazdasági főosztályon dolgozó Orosz Lajos és egy Magyar által nem ismert személy hallgatta ki. ${ }^{29}$

${ }^{25}$ ÁBTL: O-10087. Olajos Árpád tanúkihallgatási jegyzőkönyve. 1958. március 12. 30-30/1. old.

${ }^{26}$ ÁBTL: O-10087. Pető Márton tanúkihallgatási jegyzőkönyve. 1957. március 1. 31-31/1. old.

${ }^{27}$ ÁBTL: O-10087. Varga Lajos tanúkihallgatási jegyzőkönyve. 1957. február 28. 32-32/1. old.

${ }^{28}$ ÁBTL: O-10087. Klimes Lajos tanúkihallgatási jegyzőkönyve. 1957. február 28. 33-34. old.

${ }^{29}$ ÁBTL: O-10087. Magyar Miklós tanúkihallgatási jegyzőkönyve. 1957. március 1. 39-39/1. old. 


\subsection{Szőnyi Gyula ügye}

Szőnyi Gyula ügyében az operatív nyomozás során megszerzett anyagok felhasználásával újfent az érintett bűnösségét állapította meg a belügy. ${ }^{30} \mathrm{~A}$ korábbi jelentések alapján Szőnyi ellen jó néhány vádat fogalmaztak meg a hírforrások, vagyis a róla jelentést adók. Közülük igen aktív volt a már említett Naményi fedőnéven jelentő belügyi kapcsolat, akinek elmondása alapján Szőnyi a KSH Forradalmi Bizottságának és Nemzetőrségének egyik vezetője, valamint az ottani események föszervezöje volt, s kapcsolatban állt a II. kerületi „ellenforradalmi” ügyészséggel és egyéb szervekkel is. A forradalom után pedig - Naményi leírása alapján - „eszmei előkészítője annak, hogy a »forradalmi bizottság « feloszlatása után az ellenforradalmi káderek együtt maradhassanak és ezért a »forradalmi bizottság«-ot át kell menteni a szakszervezetbe." Ennek megfelelően rendszeres résztvevője volt 1957-ben is (a kapcsolattartás Naményi szerint egészen 1957 végéig tartott) a Forradalmi Bizottság egykori tagjai és a korábbi nemzetőrök találkozóinak. A Szőnyi kapcsán folytatott adatgyüjtéskor felmerült információk alapján a nemzetőrökről külön dossziét is nyitott a belügy, annak a „Nemzetőrök” nevet adva. A belügyi anyagok tovább részletezik Szőnyi ,tetteit”. Azok szerint tevékenyen részt vett már a kormányzat elleni tevékenységek eszmei előkészítésében is, s újra szóba került a két forradalmi szervben való tevékeny, sőt vezető részvétele, illetve az 1956 ősze utáni aktív magatartása is. Mint azt az összefoglalót író megemlítette, gyanú merült fel arra vonatkozólag [hogy - K. Cs.] ellenséges irányú titkos kapcsolatokkal rendelkezik. ${ }^{31}$ Másutt Szőnyi, mint a KSH Nemzetőrség parancsnokhelyettese tünt fel. ${ }^{32}$ De felrótták neki azt is, hogy azonnal csatlakozott a Zsámboki körül csoportosulókhoz, s hogy főként ő hangoztatta a KSH-ban müködő, a belügy által beépített személyek felkutatását és a forradalom ügyét szolgáló ügyészségnek történő átadásukat. Részt vett kommunista vezetők letartóztatásában és kihallgatásában. Utóbbi során, a jelentés szerint, Rédei Jenö főosztályvezetőt személyesen motozta meg, ugyanis azzal vádolta, hogy fegyveres szolgálatot látott el a VIII. kerületi pártbizottságot védve. A letartóztatott Varga Gyulát „a II. kerületi ellenforradalmi fegyveres csoporttal” ápolt jó kapcsolatai révén szabadította ki 1956. november 3-án. A vádak között szerepelt továbbá az is, hogy Szőnyi naplója olyan bejegyzéseket tartalmazott, ,amelyek alkalmasak arra, hogy a Magyar Népköztársaság és a szocialista rendszer ellen lázítsanak". Miként azt a jelentés szerzője igen szemléletesen papírra vetette: „dr. Szőnyi Gyula tevékenyen részt vett abban, hogy a KSH-ban olyan ellenforradalmi hangulat és terror légkör

\footnotetext{
${ }^{30}$ ÁBTL: O-10092. Határozat. 1958. május 28. Dr. Szőnyi Gyula ügyében az előzetes ellenőrző dosszié személyi dossziévá való átminősítéséröl. 25. old.

${ }^{31}$ ÁBTL: O-10092. Operatív intézkedési terv. 1958. február 20. „Szatmári” fn. ügyben. 29-32.

32 ÁBTL: O-10092. Nagy István tanúkihallgatási jegyzőkönyve. 1958. április 22. 38/1. old.
} 
alakuljon ki, hogy a »forradalmi bizottság« minden intézkedését ellenállás nélkül keresztül tudja vinni". ${ }^{33}$

Szőnyi ügye kapcsán ugyancsak számos tanút hallgattak meg. Olajos Árpád szerint Szőnyi nem volt tagja az MDP-nek, a rendszer elleni véleményét pedig már 1956 ősze előtt sem rejtette véka alá. A tanú elmondása szerint Szőnyi a KSH Forradalmi Bizottságának megválasztása miatti gyülés kihirdetése végett még a parlamentben és a rádióban is megfordult. ${ }^{34}$ Egy másik tanú, a vádakban megfogalmazottakhoz hasonlóan „messzebbről”, a családi háttértől indította Szőnyi politikai-közéleti megnyilatkozásait. Aszerint Szőnyinek már az apja is a KSH-ban dolgozott - szintúgy Szönyi Gyula néven - a Horthy- és a Szálasi-éra idején. Szőnyi tiszti iskolát végzett, $\mathrm{s}$ ilyen minőségében zászlósként harcolt a háború végén, majd nyugatra távozva esett francia hadifogságba. ${ }^{35} \mathrm{~A}$ tanúk vallomása alapján Móróhoz hasonlóan Szőnyi is rendelkezett a forradalom ideje alatt a KSH gépkocsiállományával, amelyet arra használtak, hogy a kihallgatásnak alávetett pártembereket és kommunista érzelmüeket szállítsák el a kihallgatás helyszínére. ${ }^{36} \mathrm{~A}$ meghallgatott tanúk sorát gyarapította Rédei Jenő is, aki föként 1956. október 31-ei kihallgatásának és motozásának körülményiről számolt be. Állítása szerint Szőnyi motozta meg fegyvert keresve, és Szőnyi volt az őt kihallgatók egyike Szalai Sándor és Laki István mellett. A nemzetőrök fegyvert kerestek nála, de nem találtak, majd páncélszekrénye kulcsát kérték, hogy a személyi anyagokat átnézhessék, s fizetését is csak azután akarták odaadni neki, miután a kulcsot átadta. Rédei elmondása alapján „Szőnyi aránylag tisztességes, humánus hangon beszélt. [...] a kihallgatás formális részének a befejeztével féligmeddig barátkozó hangon igyekezett engem meggyőzni a »forradalom« ügyéről, és hangja, magatartása nem volt ellenséges, addig - emlékezetem szerint - egy olyan megjegyzésemre, hogy mint párttag a nép ügyét akartam szolgálni, gúnyosan azt válaszolta: »Te még mindig azt hiszed, hogy a nép ügye azonos a párt ügyével«". Rédei elmondta még, hogy hallomásból tudta, a KSH-ból kitiltott kommunisták között ő is szerepelt. ${ }^{37}$ A korábban említett Klimes, Varga és Rédei mellett még Garam József neve merült fel, mint olyan személyé, akit vezetóállásúként eltávolítottak a KSH-ból. ${ }^{38}$

${ }^{33}$ ÁBTL: O-10092. Összefoglaló jelentés. 1958. május 7. Dr. Szőnyi Gyula ügyében folytatott ügynöki bizalmas nyomozásról. 111-112. old.

${ }^{34}$ ÁBTL: O-10092. Olajos Árpád tanúkihallgatási jegyzőkönyve. 1958. március 12. 36. old.

${ }^{35}$ ÁBTL: O-10092. Székely Sándor tanúkihallgatási jegyzőkönyve. 1958. április 24. 37. old

${ }^{36}$ ÁBTL: O-10092. Nagy István tanúkihallgatási jegyzőkönyve. 1958. április 22. 38. old.

${ }^{37}$ ÁBTL: O-10092. Rédei Jenő tanúkihallgatási jegyzőkönyve. 1958. április 1. 39-40. old.

${ }^{38}$ ÁBTL: O-10092. Niklai Ádám tanúkihallgatási jegyzökönyve. 1958. április 17. 42. old. 


\subsection{Az egyén és a hatalom által egyaránt elbeszélt történet: Zsámboki Zoltán ügye}

Az 1956-ban a forradalom ügye mellett szerepet vállalt KSH-tisztviselök közül Zsámboki Zoltán ügyének dossziéi teszik ki talán a legvaskosabb iratköteget, valamint az 1956 Intézet Oral History Archívuma is őriz egy vele készített életút-interjút. Mindezek révén mind tőle, mind pedig a tetteit elítélő és büntetéssel sújtó kormányzattól rendelkezésre áll forrásanyag, így egymás mellé tehetők a homlokegyenest különbözö álláspontok.

Az oral history-interjúk, a narratív, azaz elbeszélő források kapcsán leszögezhető, hogy nem feltétlenül alkalmasak kronológia vagy eseményrekonstrukció elkészítésére. Az persze nem állítható, hogy egy-egy interjúban vagy visszaemlékezésben, naplóban, önéletírásban mindössze fiktív tények, adatok és történetek hangoznak el, de az nyilvánvaló, hogy az interjúalany vagy visszaemlékező motivációja, emlékezökészsége, felkészültsége igen erősen alakítja e forrástípust (Gyáni [2000] 139-140. old.). Viszont az írott források egyoldalúsága miatt - csak a belügy készített ily típusú anyagokat - Zsámboki Zoltán interjúját igyekszem az egyes események, jelenségek bemutatásához, értelmezéséhez és főként jellemzéséhez hasznosítani, mind pedig az egykori események (re)konstrukciójához felhasználni.

$\mathrm{Az}$ interjúban Zsámboki némileg magyarázta is későbbi aktív részvételét az 1956. öszi eseményekben, a KSH-t korábbi munkahelyeivel (Országos Munkabér Megállapító Bizottság, Országos Tervhivatal, Országos Vízügyi Hivatal) összevetve ugyanis egy szakmailag jó, a politikának kevésbé kitett intézményként jellemezte, ahol meglehetősen szabad formában lehetett véleményt nyilvánítani. Miként azt megfogalmazta, „Egészen más volt a levegő, mint a többi munkahelyeimen”. ${ }^{39} \mathrm{~A}$ szociáldemokrata meggyőződésü, korábban szocdem párttag ${ }^{40}$ Zsámboki Zoltán ahogy azt az informátor Naményi is megjegyezte beszámolójában - 1955-56-ban részt vett a Petőfi Kör előadásain, ${ }^{41} \mathrm{~s}$ miután folyamatosan figyelte a közélet alakulását, jó néhány kollégájával együtt elment az 1956. október 23-ai tüntetésre is. Elmondása szerint, miután az ebédet követően visszament a hivatalba, épp gyülést tartottak, ahol ő is felszólalt, ,követeltem, hogy szavazzunk azon, hogy csatlakozunk a fiatalok tüntetéséhez. Ezt el is fogadták [...] és érdekes módon pillanatok alatt, a Zalai Júlia pillanatok alatt előkerített kokárdákat. Mentünk az épületben, mindenkinek a kezébe nyomták a kokárdát, meg egy gombostüt, ki lehetett tűzni." Ezt követően került sor a tüntetésen való részvételre, ahonnan átvonultak a parlament elé is, ahol meghallgatták Nagy Imre rögtönzött, a tömeghez intézett beszédét. Átmentek a rádió épületéhez is, de Zsámboki ott már nem maradt sokáig, hanem -

${ }^{39}$ Kovács [1987-1988] 19-20. old.

${ }^{40}$ Kovács [1987-1988] 11-15. old.

${ }^{41}$ Kovács [1987-1988] 24-25. old.

Statisztikai Szemle, 95. évfolyam 11-12. szám 
miután találkozott feleségével és egy ismerősükkel - a Sztálin-szobornál kötött ki. Onnan is eljött, még mielőtt ledöntötték volna a szobrot, de a távozás utáni időszak sem volt mentes az izgalmaktól, ugyanis Budáról már szovjet harckocsik tartottak a tüntetők irányába. Ezt követően egy eszpresszóban beszélték meg az eseményeket, majd éjfél körül hazaindultak. ${ }^{42}$

Zsámboki elmondása alapján az ELTE (Eötvös Loránd Tudományegyetem) Forradalmi Bizottságában aktív barátjától, Mérei Ferenc pszichológustól kért tanácsot október végén azt illetően, hogy mi legyen a következő lépés. Mérei fegyverek beszerzését javasolta, így Zsámboki megkezdte a KSH-ban a Nemzetőrség szervezését: „Két vagy három nap telt el azzal, hogy jártam a Rendőrfőkapitányságtól kezdve a II. kerületi Forradalmi Bizottsághoz, a Szabó bácsiékhoz, hogy adjanak fegyvert." (Az említett Szabó bácsi, Szabó János gépkocsivezető, aki a Széna téri felkelők vezetője volt 1956 őszén; tettei miatt 1957-ben kivégezték.) Zsámboki szerint a fegyverbeszerzéssel eltöltött időkiesés következtében a KSH-ban elúszott az addig kezében levő politikai vezetés. Az 1956. november 1-jén megtartott Forradalmi Bizottság választásának idejére többféle politikai csoportosulás alakult ki a hivatalban. ${ }^{43}$ Mindez egyébként leképezése volt annak a politikai-társadalomi mozgolódásnak, amely az országban zajlott, hiszen az 1945 és 1947 között müködő pártok (a kisgazdák, a kommunisták által bedarált szocdemek, a parasztpártiak stb.) közül jó néhány próbálta újjászervezni szétzilált sorait, $\mathrm{s}$ felbukkantak a palettán új csoportok is, például azok a kommunisták, akik kiábrándultak a szocialista hatalomgyakorlás rákosista módjából. ${ }^{44}$ Zsámboki elmondta, hogy a KSH-ban is megjelentek a szocdemek, megszervezték az MSZDP helyi csoportját, továbbá aktivizálódtak a kisgazdák is; ő maga november elején a II. kerületi szocdemekhez csatlakozott. Zsámboki szóba hozta a KSH Forradalmi Bizottságának egyik fő elhatározását, az intézményi vezetők és a kommunista káderek leváltására irányuló elképzelést is. Mint elmondta, abban állapodtak meg a bizottsági tagok, hogy Péter Györgyék addigi ténykedésük kivizsgálásáig fizetésüket megkapják, de a hivatalba nem járhatnak be. ${ }^{45}$

A még október végi forradalmi bizottsági választás kapcsán a Móró Károly és Szőnyi Gyula perében meghallgatott tanú is kiemelte Zsámboki Zoltán felhívását a Nemzetőrség megalakítására - elmondása alapján az több helyiségben, mintegy 50 fő részvételével zajlott. Továbbá elmondta azt is, hogy Zsámboki felvette a kapcsolatot az ELTE Jogi Karán levő fegyveresekkel. ${ }^{46}$

Zsámboki - elmondása szerint - nem ragadott fegyvert 56-ban, még akkor sem, amikor arra lehetősége lett volna, például a lakásukhoz közel eső Móricz Zsigmond

\footnotetext{
${ }^{42}$ Kovács [1987-1988] 28-29. old. Idézet: 28. old.

${ }^{43}$ Kovács [1987-1988] 30. old.

${ }^{44}$ A különféle politikai csoportok elképzeléseire 1956 őszén lásd Standeisky ([2007] 178-191. old.) írását.

${ }^{45}$ Kovács [1987-1988] 30-31. old.

${ }^{46}$ ÁBTL: O-10087. Pető Márton tanúkihallgatási jegyzökönyve. 1957. március 1.31/1. old.
} 
körtéren folyt harcok során, és november 4-én sem, amikor a szovjet támadást követően az ELTE bölcsészkarán erre lehetősége lett volna. Mint mondta: „,nem akartam a fegyveres harcot vállalni, tudtam, hogy kilátástalan". ${ }^{47}$

A fegyveres ellenállás elfojtását követően Zsámboki 1957 elejéig maradt a KSH alkalmazottja, erről így fogalmazott: ,a Statisztikából kirúgtak, gondoskodnom kellett arról, hogy miből fogok élni. [...] Akkor először lámpaernyőket próbáltam, de az nem ment, ügyetlen voltam.” Majd fordítói munkákat vállalt. ${ }^{48}$

Az 1957. januári sztrájk és tüntetés után március 15-én a karhatalom lényegében megszállta a fövárost, hogy elejét vegye a „Márciusban ÚjraKezdjük” (MUK) jelszó hatására esetlegesen kitörő újabb felkelésnek; mindemellett mindez erődemonstrációs célzatú is volt (Szakolczai [2001] 89. old.). Zsámboki Zoltánt és több egykori KSH-s kollégáját 1957 márciusában letartóztatták. Bár tíz napig őrizetben volt, úgy emlékezett, hogy mindössze egyszer hallgatták ki, s akkor is udvarias hangnemben, majd szabadon engedték. Ezt követően a következményektől tartva, felhagyott a rendszer által illegálisnak tekintett tevékenységgel. ${ }^{49}$

Zsámboki 1957 márciusában tett írásos vallomása volt az egyik első azon anyagok sorában, amely részletekbe menően mutatja meg - persze saját szemszögéből láttatva - az 1956-os KSH-beli eseményeket. Ebben például arról számolt be, hogy a lehetőségek tudatában nem akartak más helyről kapott utasítások szerint müködni, inkább saját nemzetőrség felállítását határozták el. A megalakítás után, október 31-én a nemzetőri szobában folytatott beszélgetésen merült fel, hogy a hivatal vezetöit le kellene váltani. Péter György ellen az volt a legföbb vád, hogy 1948-ban mindenféle vizsgálat nélkül 400 embert rúgott ki a hivatalból. Zsámboki aznap este, miután átgondolta a történeteket, azon a véleményen volt, eltávolításuk előtt előbb mindenképpen fel kell tárni Péter Györgyék felelősségének mértékét: „Tudtam ugyanis, hogy a hivatal vezetői felsőbb vezetőséghez intézett jelentéseikben őszintén feltárták az elkövetett súlyos hibákat és pontos képet adtak az ország életében mutatkozó súlyos problémákról." ${ }^{50}$ Niklai Ádám javaslata az volt, hogy a kormánytól kellene kérni az elnök és helyettesei leváltását, $\mathrm{s}$ helyükre nevezzenek ki egy háromtagú bizottságot; ezzel ellentétben Zsámboki többeket a vizsgálat szükségességéröl győzködött. A már többször is említett háromtagú bizottságba Thirring Lajost, Fazekas Bélát és Szalai Sándort választották be. Másnap, november 2-án Niklai viszont azt javasolta, hogy változtassák meg az intézményt irányító bizottság összetételét, tagjai pedig Thirring Lajos, Tamásy József és Barsy Gyula legyenek, ezt nem hagyták jóvá, viszont Barsy bekerült negyedik tagnak. Zsámboki november 2-án lemondott a Forradalmi Bizottság elnöki posztjáról, utódja Niklai Ádám, az ő helyettese pedig Hor-

\footnotetext{
${ }^{47}$ Kovács [1987-1988] 30., 32. old. Idézet: 32. old.

${ }^{48}$ Kovács [1987-1988] 37-38. old. Idézet: 37. old.

${ }^{49}$ Kovács [1987-1988] 37. old.

${ }^{50}$ ÁBTL: O-10087. Feljegyzés. Zsámboki Zoltán. 1957. március 20. 46. old.
} 
váth Tibor lett. Zsámboki ezt követöen - vallomása szerint - csak november 10-én ment be legközelebb a KSH-ba. Ekkor azt javasolta, hogy a Forradalmi Bizottság oszlassa fel magát, ám inkább a személyi kérdést vették elö. Az egyeztetés után Réti Pálnét, Garami Józsefet, Rédei Jenőt, Tatár Györgyöt és Mód Aladárnét ki akarták tiltani a hivatalból. A kitiltás kérdését végül az elnök és a Forradalmi Bizottság intézőbizottsága vitatta meg. A megbeszélésen Péter György nem támogatta a megnevezett személyek intézményből történő eltávolítását, s visszautasította azt az őt érintő vádat is - mondandóját bizonyítékokkal is alátámasztotta -, amely szerint „dogmatikus módon eltitkolta volna a statisztikai munka eredményeként mutatkozó tényeket." ${ }^{\circ 1}$

Talán felesleges mondani, hogy az operatív nyomozás anyagai révén Zsámboki Zoltánt bünösnek találta a belügy. Esetében az ügyészségi eljárás megkezdése előtt, 1958 májusában a következőket jegyezte fel a nyomozásban részt vevő belügyi tiszt: „a Központi Statisztikai Hivatalban fö szervezője volt az ellenforradalomi eseményeknek. [...] kapcsolatban állt a II. kerületi ellenforradalmi bizottsággal, a forradalmi értelmiségi tanáccsal, a Jogi Egyetem fegyveres csoportjával. Intézkedésére a Központi Statisztikai Hivatal ellenforradalmárai egy 40 tagú fegyveres nemzetörséget szerveztek.” Továbbá ő vezényelte le a kommunisták kitiltását az intézményből és a KSH-ban fellelhető honvédelmi iratok megszerzése végett a páncélszekrénykulcsok begyüjtését is. A november 4-i szovjet beavatkozást követő időszakból pedig azt olvasták bünként a fejére, hogy ,puccs-szerúen leváltotta a szakszervezeti bizottságot és azt a feloszlatott »forradalmi bizottság « tagjaival váltotta fel.” $\mathrm{S}$ hogy bár nem volt szakszervezeti tag, ezt a szakszervezetet ő irányította, így 1957 elején el tudott távolítani több kommunistát is a hivatalból. ${ }^{52}$

A tanúkihallgatásokból Zsámboki esetében is árnyaltabb - persze mint korábban ecseteltem, kritikával kezelendő - kép nyerhető, sőt újabb információk is felbukkannak. Olajos Árpád tanúkihallgatási jegyzőkönyve szerint Zsámboki „már az ellenforradalmat megelőzően bomlasztó tevékenységet folytatott a párton belül. Revizionista nézeteivel, terjengős hozzászólásaival a párt és a kormány vezetőit igyekezett lejáratni, a magyar-szovjet kapcsolatokat függő viszonyra lealacsonyítani”; mindezek mellett pedig a KSH vezetőinek hibáit emlegette és nagyította fel, s az intézmény éléről való eltávolításukat követelte. A tanú őt jelölte meg a történések fö szervezőjének, mint fogalmazott: ,az ellenforradalmi erők összefogója volt”. Új információ is megjelenik az anyagban: a KSH-hoz közeli utcákban falragaszok elhelyezésére és feliratok felfestésére irányuló szervezőmunka. Azonban főként a korábban már itt-ott közöltek bukkannak fel a tanúvallomásban: a helyi nemzetörség megszervezése; a II. kerületi forradalmi csoportokkal, az Értelmiségi Forradal-

${ }^{51}$ ÁBTL: O-10087. Feljegyzés. Zsámboki Zoltán. 1957. március 20. 46-48. old. Idézet: 48. old.

${ }^{52}$ ÁBTL: O-10089. Határozat. 1958. május 28. Zsámboki Zoltán ügyében személyi dosszié nyitásáról szóló. 24-25. old. 
mi Bizottsággal való kapcsolattartás; a KSH ideiglenes Forradalmi Bizottsága öszszetételének felülbírálata, majd a végleges Bizottság megválasztatása; a Szalaival, Móróval, Niklaival és Szőnyivel való együttmüködés; a kitiltandó hivatali vezetők és funkcionáriusok nevét tartalmazó lista összeállításában való részvétel; a KSHban ténykedő belügyi informátorok, ügynökök felderítésére irányuló erőfeszítések; a Forradalmi Bizottságban irányító szerep betöltése; a vezetők, pártfunkcionáriusok kihallgatásaiban való irányító szerep stb. ${ }^{53}$ Egy másik tanú időben távolabbról indította elbeszélését, azt emelte ki, hogy Zsámboki eljárt a Petőfi Kör gyüléseire, s azt követően azok tartalmát ismertette is a Közgazdasági főosztályon dolgozó kollégáival. Elmondása szerint Zsámboki emlegetette a szociáldemokrata érzelmü költővel és íróval, Jusztus Pállal való ismeretségét is. A pártok KSH-n belüli megszervezésével kapcsolatban - a tanú elmondása alapján - szóba került, hogy Zsámboki nem akart belépni az MSZMP-be (Magyar Szocialista Munkáspárt), „mert ő inkább szociáldemokrata volt és ő már aktívan részt vesz a szociáldemokrata párt szervezésében". Zsámboki a kormányzat szemében azzal is kompromittálta magát, hogy a felálló Kádár-kormányról nem nyilatkozott pozitívan, sőt kijelentette, hogy azt nem is ismeri el, ,és hogy ha felszólítanák, hogy esküdjek fel erre a kormányra, inkább veszem a kalapomat és kabátomat és elmegyek ebből a hivatalból." Mint látszik, e tanú sokkalta inkább állást foglalt az események értékelésében. Nehezményezte például, hogy 1956 végétől Zsámbokinak, bár nem volt szakszervezeti tag, vezető szerepe volt a szakszervezetben. A KSH-ból történő eltávolításáról is szót ejtett, mint megjegyezte: azt „sok huza-vona és harc előzte meg, mert a gazdasági vezetés állítólag nem látta világosan az ő ellenforradalmi aktív szerepét." ${ }^{54}$ Egy másik tanú is Zsámboki vezető szerepére mutat rá. A jegyzőkönyv alapján ugyanis, amikor Mód Aladárné egy delegációval Moszkvában tartózkodott, és felhívta a hivatalt, akkor a kagylót Zsámboki vette fel, s a „mi újság a Hivatalban, dolgoznak-e már az elvtársak?” kérdésre azt felelte, hogy „nem polgártársnő, nem dolgoznak, az emberek harcolnak, míg a szovjetek ki nem vonulnak". ${ }^{55}$

Zsámboki belügyi személyi dossziéjának összefoglaló-jelentése szerint 1956 őszén a KSH-ban az események igen aktív jellegüek voltak, s azok egészen a szélsőséges atrocitásokig elmentek. A helyi Forradalmi Bizottság tagjai a megalakított Nemeztőrség segítségével „terror légkört teremtettek”, 1-2 fö kivételével, az osztályvezetöig bezárólag kitiltották a vezetőket és a kommunista funkcionáriusokat. Az ÁVH-s besúgók nyomára akartak bukkanni, páncélszekrényeket törtek fel, őrizetbe vettek és kihallgattak embereket, kapcsolatot tartottak olyan intézményekkel, szerve-

${ }^{53}$ ÁBTL: O-10089. Olajos Árpád tanúkihallgatási jegyzőkönyve. 1958. március 12. 28-29. old. Idézet: 28., 28/1. old.

${ }^{54}$ ÁBTL: O-10089. Székely Sándor tanúkihallgatási jegyzökönyve. 1958. április 24. 30-30/1. old. Idézet: 30/1. old.

${ }^{55}$ ÁBTL: O-10089. Tatár György tanúkihallgatási jegyzőkönyve. 1958. április 23. 32. old.

Statisztikai Szemle, 95. évfolụam 11-12. szóm 
zetekkel (például az Írószövetséggel), amelyek pártellenesek voltak, uszítottak a szovjetek és a kommunista párt ellen stb. ${ }^{56} \mathrm{Az}$ ismertetett források tükrében a nyomozást végzők részéről a konklúzió: „Az ügynöki bizalmas nyomozás során megállapítottuk, hogy a KSH-ban lezajlott ellenforradalmi események fő vezetője és irányítója Zsámboki Zoltán volt". ${ }^{57}$

A Zsámboki elleni pert végül nem a KSH-ban történtekhez kapcsolták, bár amiatt tartóztatták le, hanem egy másik ügy kiegészítôperében ítélték el. Ennek okául az szolgált, hogy egy idő után a nyomozást és a kihallgatást végzők rájöttek, Zsámboki és Mérei jó kapcsolatban voltak (Gál [2009] 23. old.). Méreit az ún. Hungaricus-ügy miatt ítélték el; ez a per a későbbiekben Mérei és társai (Fekete Sándor, Széll Jenö, Hegedüs B. András, Litván György) elnevezés alatt szerepelt. A Hungaricus egy írói álnév volt, Fekete Sándor újságíróé, aki két tanulmányt is megjelentetett illegálisan. Az 1956 decemberében készült elsőt sokszorosítva terjesztették, a második viszont csak gépiratban létezett. A külföldön is ismertté vált első tanulmány a „Cikksorozat a magyar nemzeti-demokratikus forradalom néhány tanulságáról”, a második pedig a „Két pogány közt” címet viselte. Mindkettő a szovjet rendszert, annak magyarországi változatát és müködtetőit, követőit mutatta be, illetve bírálta, mégpedig igen olvasmányos és gúnyos stílusban, továbbá az ellenállás lehetőségét is felvetette (Gál [2009] 11-13. old.). A vád az írás szerkesztése, sokszorosítása és terjesztése volt (Gál [2009] 9. old.). A per tulajdonképpeni célja a Nagy Imre elveit, nézeteit valló, de még nem letartóztatott vagy akár el is ítélt értelmiségiek csoportjának felszámolása, illetve megfélemlítése volt (Gál [2009] 10. old.). Zsámboki elmondása szerint annyi köze volt az ügyhöz, hogy a Hungaricus-tanulmányok első részéhez stencilpapírt szerzett a KSH-ból, valamint két példányát tovább adva tulajdonképpen terjesztette is azt. Mindezekből kifolyólag azonban a belügy összekapcsolta személyét Méreiével, Feketéével és a többiekével, így kreálva nagyobbá a Hungaricus-ügyet. ${ }^{58}$

A Zsámboki és nyolc társa (Kántás László, Hoffmann Tiborné, Kelemen Imre, Nemes Livia, Kiss Károly, Németh László, Varga János, Lipták Tamás) elleni per 1959. június 2-án meghozott ítéletében egytől hét évig terjedő börtönbüntetéssel sújtották a vádlottakat, Zsámboki Zoltánt a leghosszabbal, ő hét évet kapott (Gál [2009] 68-69. old.). A rá kiszabott büntetést - az előzetesben eltöltött, valamint a per ideje alatti időszakot is beszámítva - 1958. június 10-én kezdte meg, és 1963. február 10-én szabadult. ${ }^{59}$

${ }^{56}$ ÁBTL: O-10089. Összefoglaló jelentés. 1958. május 7. Zsámboki Zoltán ügyében folytatott ügynöki bizalmas nyomozásról. 61-62. old.

${ }^{57}$ ÁBTL: O-10089. 62. old.

${ }^{58}$ Zsámboki Zoltán-interjú. 38-39. old.

${ }^{59}$ ÁBTL: V-166931/8. Zsámboki Zoltán. 1990. 617. old. 


\section{Az elbeszélő forrásokból kibontakozó kép}

Az ismert demográfusnak, Thirring Lajosnak (Kovács-Thirring [2014]) a mindössze pár hónappal halála előtt, 1983 januárjában lejegyzett visszaemlékezése szerint, 1956 végén őt jobban foglalkoztatta a télre való tüzelő és élelmiszer beszerzése „pld. a Margit-hídtól $100 \mathrm{~kg}$ szenet hordtam föl hátizsákban a Bimbó-útra”, mint a hivatalban zajló események. Ugyanis, mint azt papírra vetette: „A magam részéről egyébként azért is kerültem a hivatalba való belátogatást, mert reménytelennek láttam a helyzetet, biztosra vettem, hogy nem maradhatunk szabadok, a szovjet uralom nem enged ki kötelékéből." ${ }^{\prime 60}$ Thirring életére jelentős hatással volt ugyanakkor az, hogy állásának elvesztésétől tartva, részt vett egy nagygyülésen, ahol az aktuális vezetőség leváltását követelő megjelentek őt szándékoztak a „Duna jegén” a KSH új vezetőjének kinevezni. Thirring elmondása szerint az ülés elött, amelyen őt megválasztották, jelezte Zsámboki Zoltánnak, hogy az elnöki posztot nem kívánja elfogadni, ugyanis „munkahelyemmel meg vagyok elégedve és ki tudja, milyen változás következik be és akkor feleslegessé válok". Ezek után a hivatal vezetésére egy három főből álló bizottság megszervezését tartották volna megfelelőnek, Thirring elmondása szerint részt vett volna a bizottság munkájában, maga mellett pedig Fazekas Bélát és Szalai Sándort javasolta, további javaslatra pedig negyedik tagként felmerült Barsy Gyula személye, azonban „A szovjet beavatkozás következtében ez a munkabizottság éppúgy nem kezdte meg tevékenységét, mint egy másik bizottság, amely a hivatalban elkövetett hibákat óhajtotta számba venni". ${ }^{61}$ Vagyis, mint látszik, Thirring komoly szerepet nem vállalt 1956 öszén, ennek ellenére Thirring úgy érezte, nem sokáig lesz maradása a KSH-ban: „biztosra vettem, hogy el fognak távolítani”. Igaza lett, 1959 januárjában - amikor már csak három hónapja volt hátra nyugdíjazásáig, s négyhónapnyi idő hiányzott 40 éves szolgálati jubileumához - elbocsájtották állásából. Szaktudása idővel nélkülözhetetlennek bizonyult, így 1969 tavaszán visszahívták, s egészen 1983 májusában bekövetkezett haláláig újfent a hivatal szolgálatában állt. ${ }^{62}$

\section{Könyvtáros a forradalomban}

Egy fiatal könyvtáros, Füzéki István révén a KSH Könyvtár is kivette a részét az 1956-os eseményekből. Az 1934 nyarán született Füzéki 1956-ban lépett a

${ }^{60}$ Thirring [1983] 7. old.

${ }^{61}$ Thirring [1983] 8. old.

${ }^{62}$ Thirring [1983] 9-10. old.

Statisztikai Szemle, 95. évfolyam 11-12. szám 
könyvtár kötelékébe, közvetlenül azután, hogy az ELTE BTK (Bölcsészettudományi Kar) könyvtár szakán megszerezte a diplomáját. Könyvtári munkája nem volt teljes állás, csak félnapokra alkalmazták raktári teendők ellátására (Rózsa [2013] 26. old.). Kötődése valószínűleg oly erős lehetett korábbi egyeteméhez, továbbá a KSH-n belül nem szerveződött fegyveres ellenállás, hogy 1956 öszén az ELTE BTK-n teljesített nemzetőri szolgálatot. Füzéki és bölcsésztársai a jogi kar épületét jobban védhetőnek ítélték, mint a bölcsészkarét, így november 6-án az Egyetem téren érte őket a szovjet támadás; a túlerő ellen fegyvert ragadók a visszaemlékezések szerint 35-40-en lehettek. Hamar legyürték őket, s fogságba kerültek. Az viszszaemlékezések szerint Füzékit nem vetették börtönbe társaival együtt, ugyanis amikor egy szovjet tiszt sértegette, lefasisztázta őket oroszul, a fiatalember orosz nyelven válaszolt a tisztnek, hogy ez az ő országa, s a szovjetek a fasiszták. A szóváltás után a foglyul ejtetteket egy másik helyre terelték át, a fiatal könyvtáros azonban eltűnt társai szeme elől, az őrök kiemelték a többiek közül, egyszerúen nyoma veszett. Valószínü, hogy minden hezitálás nélkül kivégezték. Napokkal az események után családja megtalálta személyi iratait a postaládájukban (Horváth [2002a] 25-26. old., [2002b]).

\section{6. Összegzés}

Rövid összegzésként mindössze két dolgot emelek ki. Egyrészt a KSH az 1956-os események után - kormányzati felszólításra - igen részletes kimutatást készített az országos veszteségekről. Az összesítő adatok szerint hozzávetőleg 2700 halottja és mintegy 20 ezer sebesültje volt a harcoknak (KSH [1957a] 1-2. old.). A közöltnél nagyobb lehetett azonban az áldozatok száma, ugyanis egyes esetekben az anyakönyvi bejegyzések természetes halálként tüntették fel a lőtt sebek okozta halálozást (Hegedüs [1996] 303. old.). Az 1957. április 30-án készített mérleg szerint mindez kiegészült a majd 194 ezer külföldre menekülttel (KSH [1957b] 1. old.); összességében 211 ezren hagyták el az országot 1956 végén, 1957 elején, s közülük 170 ezer fö nem is tért haza (Romsics [2010] 406. old.). A szovjet veszteség is jelentős volt, 669 fő elesett, 1540 katona megsebesült, 51-en pedig eltüntek a harcok során (Hegedüs [1996] 307. old.). Másrészt pedig - és jelen munka megírásakor főként ez motivált - arra törekedtem, hogy a KSH-ról szóló, egymáshoz képest meglehetősen eltérő forrástípusok minél több jellemzőjére rávilágítva bemutassam a hivatalban 1956 őszének történéseit és azok szereplöinek eddig meglehetősen elhanyagolt, jóformán feledésbe merült történetét. 


\section{Forrás}

ÁBTL (Állambiztonsági SzolgÁlatok TÖRTÉnEti LevÉltÁra): O-19827. I. köt. Központi Statisztikai Hivatal. Objektumdosszié.

ÁBTL: V-150361/1. 1956-os monográfia. Minisztériumok, budapesti iparvállalatok és főhatóságok.

ÁBTL: V-166931/8. Zsámboki Zoltán. Semmisségi igazolások R-Zs-ig.

ÁBTL: B-83736. Paprikás fn. ügynök jelentései.

ÁBTL: O-10087. Móró Károly személyi dossziéja.

ÁBTL: O-10092. dr. Szőnyi Gyula személyi dossziéja.

ÁBTL: O-10089. Zsámboki Zoltán személyi dossziéja.

KovÁCs A. [1987-1988]: Interjú Zsámboki Zoltán müforditó, statisztikus, szerkesztővel. Országos Széchényi Könyvtár. 1956-os Intézet Oral History Archívuma. 111. sz. Budapest.

THIRRING L. [1983]: Visszaemlékezések statisztikai-demográfiai pályafutásomra. KSH Könyvtár kézirattár. Thirring Lajos-hagyaték 96. d. Január 20.

\section{Irodalom}

Fenyvesi L.-né - KovÁCs Cs. - NÁdudvari Z. [2014]: Zala Júlia. In: Rózsa D. (főszerk.): Portrék a magyar statisztika és népességtudomány történetéböl. Életrajzi lexikon a XVI. századtól napjainkig. KSH Könyvtár. Budapest. 758-759. old.

GÁL É. [2009]: Mérei Ferenc és társai „ellenforradalmi szervezkedése” 1957-1959. In: Tischler J. (szerk.): Kádárizmus mélyfúrások. Évkönyv XVI. 1956-os Intézet. Budapest. 9-74. old.

GYÁNI G. [2000]: Emlékezés, emlékezet és a történelem elbeszélése. Napvilág Kiadó. Budapest.

Hegedüs B. A. [1989]: A jegyzőkönyvek elé. In: Hegedüs B. A. - Rainer M. J. (szerk.): A Petőfi Kör vitái hiteles jegyzökönyvek alapján. I. Két közgazdasági vita. Kelenföld Kiadó, Eötvös Loránd Tudományegyetem. Budapest. 7-32. old.

Hegedüs B. A (föszerk.) [1996]: 1956 kézikönyve. III. kötet. Megtorlás és emlékezés. 1956-os Intézet. Budapest.

HoRvÁTH T. [2002a]: Füzéki István emlékezete. Könyv, könyvtár, könyvtáros. 11. évf. 12. sz. 2228. old.

HoRVÁTH T. [2002b]: Emlékezés Füzéki Istvánra. In: Füzeki István emlékezete. Magyar Könyvtárosok Egyesülete. Budapest. 5-11. old.

KovÁcs Cs. - MARTON Á. - NÁDudvari Z. [2014]: Péter György. In: Rózsa D. (föszerk.): Portrék a magyar statisztika és népességtudomány történetéböl. Életrajzi lexikon a XVI. századtól napjainkig. KSH Könyvtár. Budapest. 575-577. old.

KovÁcs Cs. - ThiRring L. [2014]: Thirring Lajos. In: Rózsa D. (főszerk.): Portrék a magyar statisztika és népességtudomány történetéböl. Életrajzi lexikon a XVI. századtól napjainkig. KSH Könyvtár. Budapest. 703-705. old.

KSH (KÖZPONTI StATISZTIKAi HivATAL) [1957a]: Szociális és kultúrstatisztikai jelentés. Az október 23-ai és az azt követö eseményekkel kapcsolatos sérülések és halálozások. Budapest.

KSH [1957b]: Az illegálisan külföldre távozott személyek föbb adatai. Budapest. 
PAJCSICS J. [2006]: Öngyilkosságok és leszámolások a Kádár-korban. Péter György halálesete. Rendészeti Szemle. 54. évf. 11. sz. 102-109. old.

RoMsics I. [2010]: Magyarország története a XX. században. Osiris Kiadó. Budapest.

Rózsa D. (szerk.) [2013]: Portrék a Központi Statisztikai Hivatal Könyvtárának másfél évszázadából. KSH Könyvtár. Budapest.

STANDEISKY É. [2007]: Eszmék az 1956-os forradalomban. In: Gyáni G. - Rainer M. J. (szerk.): Ezerkilencszázötvenhat az újabb történeti irodalomban. 1956-os Intézet. Budapest. 222-253. old.

SZAKolcZAi A. [2001]: Az 1956-os forradalom és szabadságharc. 1956-os Intézet. Budapest.

\section{Summary}

This paper presents the occurrences happened in the HCSO (Hungarian Central Statistical Office) during the 1956 Hungarian Revolution and War of Independence and in the subsequent months. It is founded not only on the relevant literature but also on many other sources (e.g. documents of the Ministry of the Interior, documentation on the investigation of the 1956 autumnwinter events, narrative sources such as life interviews, memoirs, etc.). The article allows the reader to get an insight into the activity of the revolutionary organisations (the revolutionary committee and the National Guard) and to learn the portraits of those HCSO's workers who played key roles in the events. 